ARTICLE

DOI: $10.1038 / s 41467-018-06763-4$

\title{
A selenium-catalysed para-amination of phenols
}

\author{
Dingyuan Yan', Guoqiang Wang², Feng Xiong1, Wei-Yin Sun', Zhuangzhi Shi (D) 1, \\ Yi Lu', Shuhua Li (iD ${ }^{2} \&$ Jing Zhao (ID ${ }^{1}$
}

Antioxidant enzyme glutathione peroxidase (GPx) decomposes hydroperoxides by utilizing the different redox chemistry of the selenium and sulfur. Here, we report a Se-catalysed paraamination of phenols while, in contrast, the reactions with sulfur donors are stoichiometric. A catalytic amount of phenylselenyl bromide smoothly converts $\mathrm{N}$-aryloxyacetamides to $\mathrm{N}$ acetyl $p$-aminophenols. When the para position was substituted (for example, with tyrosine), the dearomatization 4,4-disubstituted cyclodienone products were obtained. A combination of experimental and computational studies was conducted and suggested the weaker $\mathrm{Se}-\mathrm{N}$ bond plays a key role in the completion of the catalytic cycle. Our method extends the selenium-catalysed processes to the functionalisation of aromatic compounds. Finally, we demonstrated the mild nature of the para-amination reaction by generating an AlEgen 2-(2'hydroxyphenyl)benzothiazole (HBT) product in a fluorogenic fashion in a PBS buffer.

\footnotetext{
${ }^{1}$ State Key Laboratory of Coordination Chemistry, Institute of Chemistry and BioMedical Sciences, School of Chemistry and Chemical Engineering, School of Life Sciences, Nanjing University, 210093 Nanjing, China. ${ }^{2}$ Key Laboratory of Mesoscopic Chemistry of Ministry of Education, Institute of Theoretical and Computational Chemistry, School of Chemistry and Chemical Engineering, Nanjing University, 210093 Nanjing, China. These authors contributed equally: Dingyuan Yan, Guogiang Wang, Feng Xiong. Correspondence and requests for materials should be addressed to Y.L. (email: luyi@nju.edu.cn) or to S.L. (email: shuhua@nju.edu.cn) or to J.Z. (email: jingzhao@nju.edu.cn)
} 
S elenium is an essential biological trace element discovered by Jöns Jacob Berzelius in $1818^{1}$. The selenium analogue of cysteine, known as selenocysteine ${ }^{2-4}(\mathrm{Sec})$, is the main biological form of selenium. The most studied selenoenzyme glutathione peroxidase (GPx) has an Sec residue in its active site that is responsible for decomposing hydroperoxides (Fig. 1a) ${ }^{5,6}$. Besides, the flavin-containing redox enzyme thioredoxin reductase $(\operatorname{TrxR})^{7-9}$ and the deiodinating enzyme iodothyronine deiodinase (ID) $)^{10,11}$ represent other key selenium-containing enzymes in biocatalysis.

Selenium-containing small molecules, such as ebselen and its analogues, have also exhibited important antioxidant activity as GPx mimics ${ }^{12-15}$. Organoselenium-catalysed reactions have been widely employed in a number of different reactions ${ }^{16-18}$, and substantial progress has been made by Breder ${ }^{19-21}$, Wirth ${ }^{22-24}$, Denmark $^{25,26}$, Yeung ${ }^{27}$ and Zhao ${ }^{28-31}$ in recent years. Notably, selenium has emerged as appropriate alternatives to precious metals as catalysts for the construction of $\mathrm{C}-\mathrm{N}$ bonds ${ }^{32-34}$. Breder et al. discovered an elegant selenium-catalysed amination of allyl and vinyl using $N$-fluorobenzenesulfonimide as oxidant and nitrogen source $^{35}$. Furthermore, Zhao et al. accomplished a powerful pyridination of 1,3 -dienes using $(\mathrm{BnSe})_{2}$ as a catalyst ${ }^{36}$ (Fig. 1b). However, no selenium-catalysed processes for the functionalisation of aromatic compounds have been developed. One challenge might be the electrophilic selenium catalysts react with the aryl rings directly, leading to the deactivation of catalyst ${ }^{37,38}$. We thought that a more nucleophilic site, to accommodate with selenium catalyst temporarily, might be helpful for competing with the deactivation. We herein report a strategy to first form an intermediate with an adjacent, redox versatile $\mathrm{Se}-\mathrm{N}$ bond which undergoes two successive sigmatropic rearrangements to generate the para-amination product and regenerate the selenium catalyst (Fig. 1c).

a

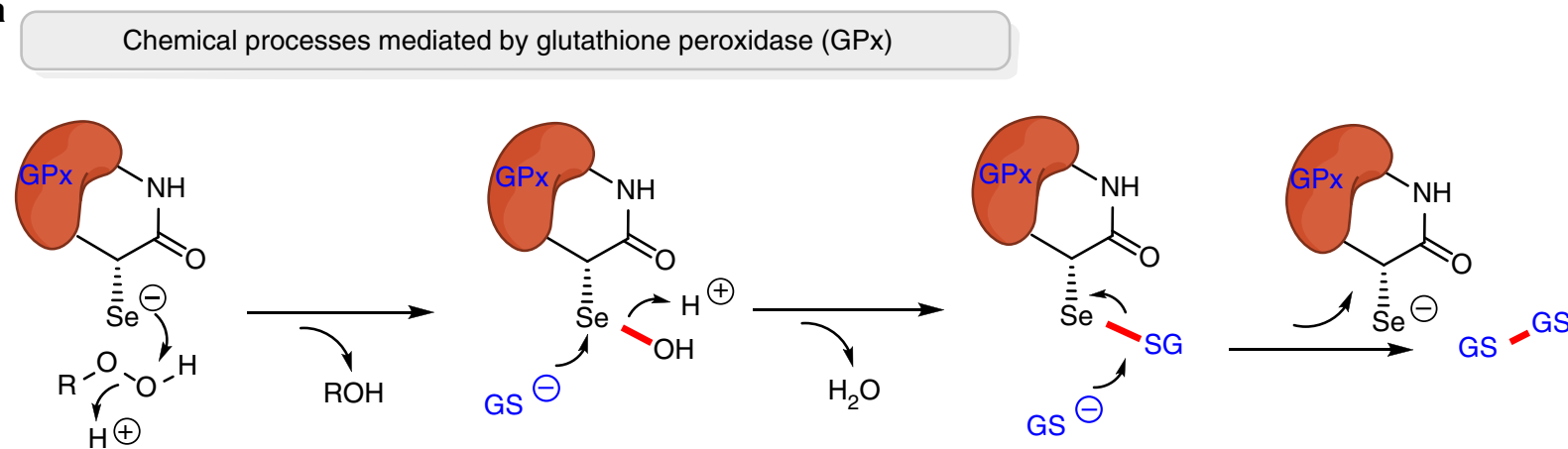

b

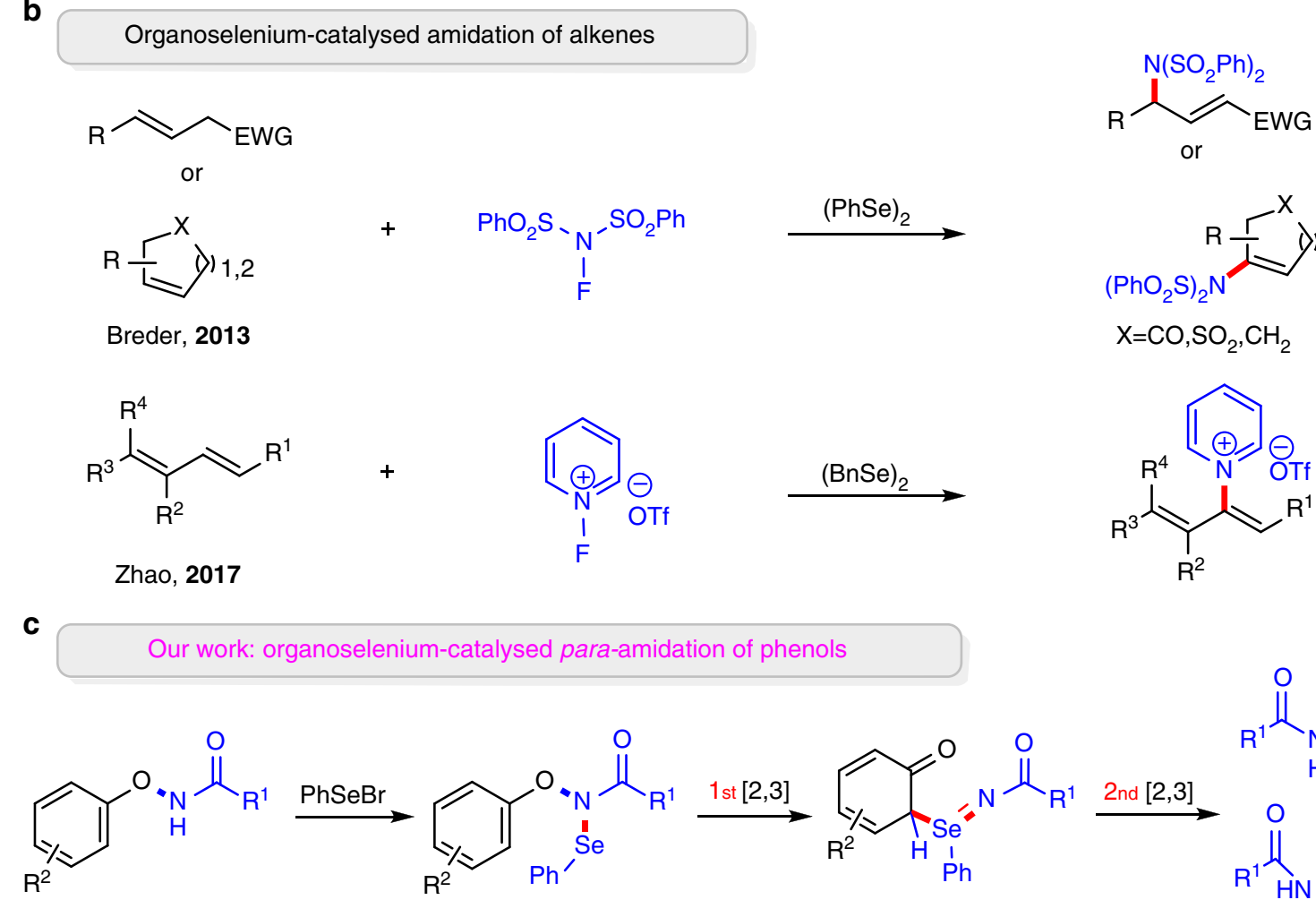

Organoselenium-catalysed amidation of alkenes

or

Breder, 2013

Zhao, 2017

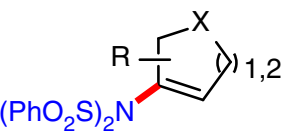

$$
\mathrm{X}=\mathrm{CO}, \mathrm{SO}_{2}, \mathrm{CH}_{2}
$$

\section{C} Our work: organoselenium-catalysed para-amidation of phenols<smiles>[R7]C(=O)NC1([R])C=CC(=O)C=C1NC([R7])[R]</smiles>

Fig. 1 Selected biological reaction and organic reactions catalysed by selenium. a Proposed catalytic cycle of glutathione peroxidase (GPx) for the reduction of hydroperoxides in biology. b Previous reports on organoselenium-catalysed amination of alkenes. GS- glutathione. c Our double [2,3]-sigmatropic rearrangement to achieve para-amination of phenols 


\section{Table 1 Substrate scope of Se-catalysed para-amination of phenols ${ }^{a}$}<smiles>[R]C(=O)NOc1ccccc1[R]</smiles>

$$
\underset{\text { 1,4-dioxane, r.t., } 8 \mathrm{~h}}{\stackrel{\mathrm{PhSeBr}}{\longrightarrow}}
$$<smiles>[R]CC(=O)Nc1ccc(O)cc1</smiles><smiles>CC(=O)Nc1ccc(O)cc1</smiles>

2a, $90 \%$<smiles>CC(=O)Nc1ccc(O)c(Cl)c1</smiles>

2e, $65 \%$<smiles>COc1cc(O)ccc1NC(C)=O</smiles>

2i, $74 \%$<smiles>CC(C)(C)OC(=O)Nc1ccc(O)cc1</smiles>

$2 \mathrm{~m}, 76 \%$<smiles>O=C(Nc1ccc(O)cc1)c1ccccc1</smiles>

2p, $87 \%$<smiles>CC(=O)Nc1ccc(O)c(C)c1</smiles>

2b, $73 \%$<smiles>CCc1cc(NC(C)=O)ccc1O</smiles>

2c, $83 \%$<smiles>CC(=O)Nc1ccc(O)c(Br)c1</smiles>

2d, $78 \%$<smiles>CC(=O)Nc1ccc(O)cc1C</smiles>

2f, $82 \%$<smiles>CC(=O)Nc1ccc(O)cc1F</smiles>

2g, $83 \%$<smiles>CC(=O)Nc1cc(C)c(O)c(C)c1</smiles>

2k, $92 \%$

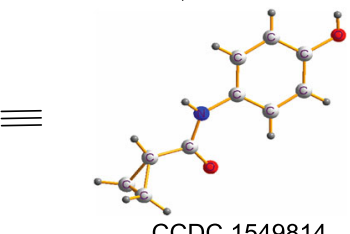<smiles>CC(=O)Nc1ccc(O)cc1Br</smiles>

2h, $67 \%$
$2 \mathrm{j}, 62 \%$<smiles>O=C(Nc1ccc(O)cc1)C1CC1</smiles>

2n, $85 \%$<smiles>O=C(Nc1ccc(O)cc1)c1ccccn1</smiles>

2q, $80 \%$<smiles>O=C(Nc1ccc(O)cc1)c1cccs1</smiles>

$2 \mathbf{r}, 67 \%$<smiles>CC(=O)Nc1ccc(O)c2ccccc12</smiles>

2I, $54 \%$<smiles>[Y]C(=O)Nc1ccc(O)cc1</smiles>

2o, $53 \%$<smiles>Cc1ccc(S(=O)(=O)Nc2ccc(O)cc2)cc1</smiles>

2t, $86 \%$<smiles>CC(=O)Nc1cc(Oc2ccc(Cl)cc2Cl)c(O)cc1Cl</smiles>

astandard conditions: $1(0.20 \mathrm{mmol})$, $\mathrm{PhSeBr}(10 \mathrm{~mol} \%)$, 1,4-dioxane $(2.0 \mathrm{~mL})$, at ambient temperature for $8 \mathrm{~h}$. Isolated yield

\section{Results}

Model reactions and substrate scope. We started by treating $N$ phenoxyacetamide (1a) with 1.0 equiv. of $N$-phenylselanylphthalimide (C1); we observed the para-aminated phenol (2a, acetaminophen) in $47 \%$ yield. To our delight, when catalytic amount of C1 (10 mol\%) was used, 2a can be obtained in $38 \%$ yield (Supplementary Table 1, entries $1-3$ ). This result compelled us to explore other organoselenium reagents that might catalyse this reaction. No product was detected when diphenyl diselenide (C2) and diphenylselane (C3) were used
(Supplementary Table 1, entries 4 and 5). Both $\mathrm{PhSeCl}$ (C4) and $\mathrm{PhSeBr}$ (C5) proved to be efficient catalysts in 2,2,2-trifluoroethanol (TFE) with 60 and $79 \%$ yields, respectively (Supplementary Table 1, entries 6 and 7). Screening of a variety of solvents (including $\mathrm{MeOH}, \mathrm{DMSO}$, THF, MeCN, EA) indicated that 1,4-dioxane was the best solvent (93\% NMR yield and $90 \%$ isolated yield of the desired product, Supplementary Table 1, entries 8-13). Ultimately, the optimal reaction conditions employed $10 \mathrm{~mol} \% \mathrm{PhSeBr}(\mathrm{C5})$ in 1,4-dioxane at room temperature in air. 
Table 2 Substrate scope of Se-catalysed dearomatization reaction ${ }^{a}$

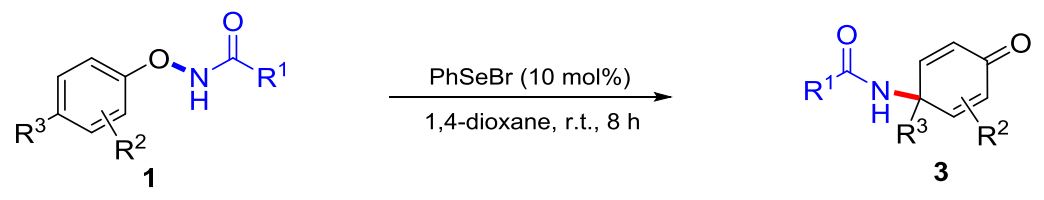<smiles>CC(=O)NC1(C)C=CC(=O)C=C1</smiles>

3a, $78 \%$<smiles>CCCC1(NC(C)=O)C=CC(=O)C=C1</smiles>

3e, $82 \%$<smiles>CC(=O)NC1(C)C=CC(=O)C=C1C</smiles>

3b, $87 \%$<smiles>CCC(=O)NC1(C)C=CC(=O)C=C1</smiles>

3f, $80 \%$<smiles>CC(=O)NC1(C)C=CC(=O)C(Cl)=C1</smiles>

$3 c, 78 \%$<smiles>CC(C)C(=O)NC1(C)C=CC(=O)C=C1</smiles>

3g, $61 \%$<smiles>CCC1(NC(C)=O)C=CC(=O)C=C1</smiles>

3d, $75 \%$<smiles>CC(=O)NC(CC1(NC(C)=O)C=CC(=O)C=C1)C(C)=O</smiles>

3h, $56 \%$

aStandard conditions: 1 (0.20 mmol), PhSeBr (10 mol\%), 1,4-dioxane $(2.0 \mathrm{~mL})$, at ambient temperature for $8 \mathrm{~h}$. Isolated yield

The optimized reaction conditions proved to be effective with a number of other substituents on $N$-phenoxyacetamides (Table 1). $\mathrm{N}$-phenoxyacetamides with electron-rich or electron-deficient substituents reacted smoothly to give the desired para-C-H amination products $(\mathbf{2 a}-\mathbf{k})$ in moderate to excellent yields $(62$ $-92 \%)$. Electronic effects did not significantly influence the outcomes of the reactions. $\mathrm{N}$-phenoxyacetamides bearing fluoro-, bromo-, and chloro-substituents $(\mathbf{2} \mathbf{d}-\mathbf{e}, \mathbf{2} \mathbf{g}-\mathbf{h}, \mathbf{2 j})$ were successfully subjected to this simple protocol with yields from 62 to $83 \%$. The reaction condition was applicable to yield aminated naphthol (2l) in $54 \%$ yield.

To further expand the scope of this highly para-selective amination process, we investigated different $N$-phenoxyamides. $\mathrm{N}$-phenoxyamide with the Boc-substituent on nitrogen afforded the corresponding product $\mathbf{2 m}$ in $76 \%$ yield. When the acetyl group was replaced by other aliphatic groups such as cyclopropanecarbonyl and hexanoyl groups, the reactions proceeded smoothly to afford the desired products $\mathbf{2 n}$ and 20 in 85 and 53\% yield, respectively. Replacing the acetyl group with aromatic amides or sulfonamide also furnished the desired phenols $(\mathbf{2} \mathbf{p}-\mathbf{t})$ in good yields $(64-87 \%)$. When we applied the method to the late-stage modification of an antifungal drug Triclosan, the desired para-aminated product $(\mathbf{2 u})$ was isolated successfully in $83 \%$ yield.

The oxidative amination/dearomatization reaction. When the para-methyl-substituted substrate was employed, we obtained the dearomatization product $\mathbf{3 a}$ in $78 \%$ yield (Table 2). Efficient oxidative amination of phenols was also obtained when ethyl, propyl was present at the para site under standard reaction condition. However, we did not detect any of the dienones when methyl was replaced with bulkier substituents, such as isopropyl and tert-butyl groups. In those cases, only the corresponding phenols were isolated. Replacing the acetyl group with the propionyl or isobutyryl group on nitrogen gave $\mathbf{3 f}$ and $\mathbf{3 g}$ in 80 and $61 \%$ yield, respectively. Finally, protected tyrosine underwent oxidative amination to give $3 \mathbf{h}$ in $56 \%$ yield under standard conditions.
The stoichiometric sulfur-mediated reaction. The success in the Se-catalysed synthesis of $p$-aminophenols or dienones prompted us to attempt to develop a similar sulfur-catalysed version which could display good catalytic activity as organochalcogen catalysis ${ }^{39-43}$. However, when a solution of 1a was treated with $10 \mathrm{~mol} \% 2$-( $p$-tolylthio)isoindoline-1,3-dione (4a) at ambient temperature over a period of $5 \mathrm{~h}$, we detected a trace amount of para-aminated product (5a) with a preserved $\mathrm{N}-\mathrm{S}$ bond. When the amount of $\mathbf{4 a}$ was increased to 1.2 equiv., para-aminated product (5a) was obtained in $38 \%$ yield. An extensive screening of bases (e.g. pyridine, CsOAc, 2,6lutidine, DMAP, $\mathrm{Na}_{2} \mathrm{CO}_{3}, \mathrm{DBU}$, DIPEA) was conducted and revealed that 2,6-lutidine gave the desired para-aminated product 5a in 53\% yield. Further optimization established TFE as the best solvent for this transformation, providing the paraaminated phenol in $84 \%$ isolated yield (Supplementary Table 2).

With the optimal reaction conditions established, we investigated a series of $N$-phenoxyacetamide substrates (Table 3). Ortho-substituted $N$-phenoxyacetamides delivered the desired para-aminated phenols in good to excellent yields $(5 \mathbf{a}-5 \mathbf{c})$. When the $N$-protecting group was replaced by other aliphatic amides such as cyclopropanecarbonyl and propionyl groups, the reactions proceeded smoothly to afford desired products $\mathbf{5 e}$ and $\mathbf{5 f}$ in 45 and $80 \%$ yield, respectively. The reaction proceeded smoothly with both substrates bearing electron-donating group (5h) and halogen-containing $N$ substituted phthalimides $(5 \mathbf{i}-\mathbf{m})$.

Mechanistic study. A series of experiments were conducted to probe the reaction mechanism. The ortho-sulfiliminyl phenol $\mathbf{5} \mathbf{g}^{\prime \prime}$ could not transfer to para-aminated product $5 \mathrm{~g}$ under standard reaction conditions (Supplementary Fig. 1a). We could not detect any desired product and most of the starting material was recovered when $N$-methyl-substituted phenoxyacetamide (1w) was used under the S/Se-mediated reaction conditions, indicating the indispensable role of the N-H bond (Supplementary Fig. 1b). When compounds 1 a and $d_{8}$-1a were used as substrates under S- 
<smiles>[R]C(=O)N(Sc1ccc([R])c(SN2C(=O)c3ccccc3C2=O)c1)c1ccc(O)cc1</smiles><smiles>C#CC</smiles>

5a, $84 \%$<smiles>Cc1ccc(SN(C(=O)OC(C)(C)C)c2ccc(O)cc2)cc1</smiles>

5d, $42 \%$<smiles>COc1ccc(SN(C(C)=O)c2ccc(O)cc2)cc1</smiles>

5h, $75 \%$<smiles>CC(=O)N(Sc1cccc(Br)c1)c1ccc(O)cc1</smiles>

$51,74 \%$

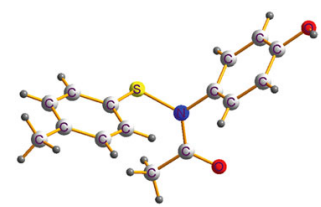

CCDC 1570955<smiles>CC(=O)N(Sc1ccc(F)cc1)c1ccc(O)cc1</smiles>

$5 i, 66 \%$<smiles>CC(=O)N(Sc1ccccc1Br)c1ccc(O)cc1</smiles>

5m, $66 \%$<smiles>CC(=O)N(Sc1ccc(C)cc1)c1ccc(O)c(C)c1</smiles>

5b, $82 \%$<smiles>CCC(=O)N(Sc1ccc(C)cc1)c1ccc(O)cc1</smiles>

5f, $80 \%$<smiles>CCc1cc(N(Sc2ccc(C)cc2)C(C)=O)ccc1O</smiles>

5c, $83 \%$<smiles>CC(=O)N(Sc1ccccc1)c1ccc(O)cc1</smiles>

5g, $85 \%$<smiles>CC(=O)N(Sc1ccc(Cl)cc1)c1ccc(O)cc1</smiles>

5j, $76 \%$<smiles>CC(=O)N(Sc1ccc([N+](=O)[O-])cc1)c1ccc(O)cc1</smiles>

5n, $72 \%$

aStandard conditions: $1(0.20 \mathrm{mmol}), \mathbf{4}(0.24 \mathrm{mmol}), 2,6$-lutidine (1.0 equiv.), TFE (2.0 mL), at ambient temperature for $5 \mathrm{~h}$ Isolated yield. TFE, 2,2,2-trifluoroethanol

mediated reaction conditions, the HRMS data showed that the para amide transfer via an intramolecular pathway and the mixed acetamide migration products were not detected. In addition, a crossover experiment was carried out between equimolar amount of $\mathbf{1 a}$ and $d_{8}$-1a under Se-catalysed reaction conditions in one reactor. Only the intramolecular amides transformation of phenols (2a, $d_{7}$-2a) were obtained (Supplementary Fig. 1c and Supplementary Fig. 13).

Based on the preliminary studies, the mechanism of this organoselenium-catalysed para-selective $\mathrm{C}-\mathrm{H}$ bond amination is proposed in Fig. 2. The electrophilic Se species could react with the mildly basic $N$-phenoxyacetamide 1 a to give the $\mathrm{Se}-\mathrm{N}$ intermediate (INT1-Se) together with the release of one molecule of HBr. Then, the INT1-Se undergoes two successive [2,3]sigmatropic rearrangements ${ }^{44-49}$ to generate the para-amination intermediate (INT3-Se), which may readily react with $\mathrm{HBr}$ and then rearomatize to the desired product $\mathbf{2 a}$ (for details see Supplementary Figs 4-11).

DFT calculations. We performed density functional theory (DFT) calculations to explore the mechanistic details for these S (and Se)-mediated para-selective nitrogen migration of $\mathrm{N}$-aryloxyacetamides (Fig. 3). All calculations were carried out with the B3LYP functional ${ }^{50,51}$, augmented with Grimmes D3 


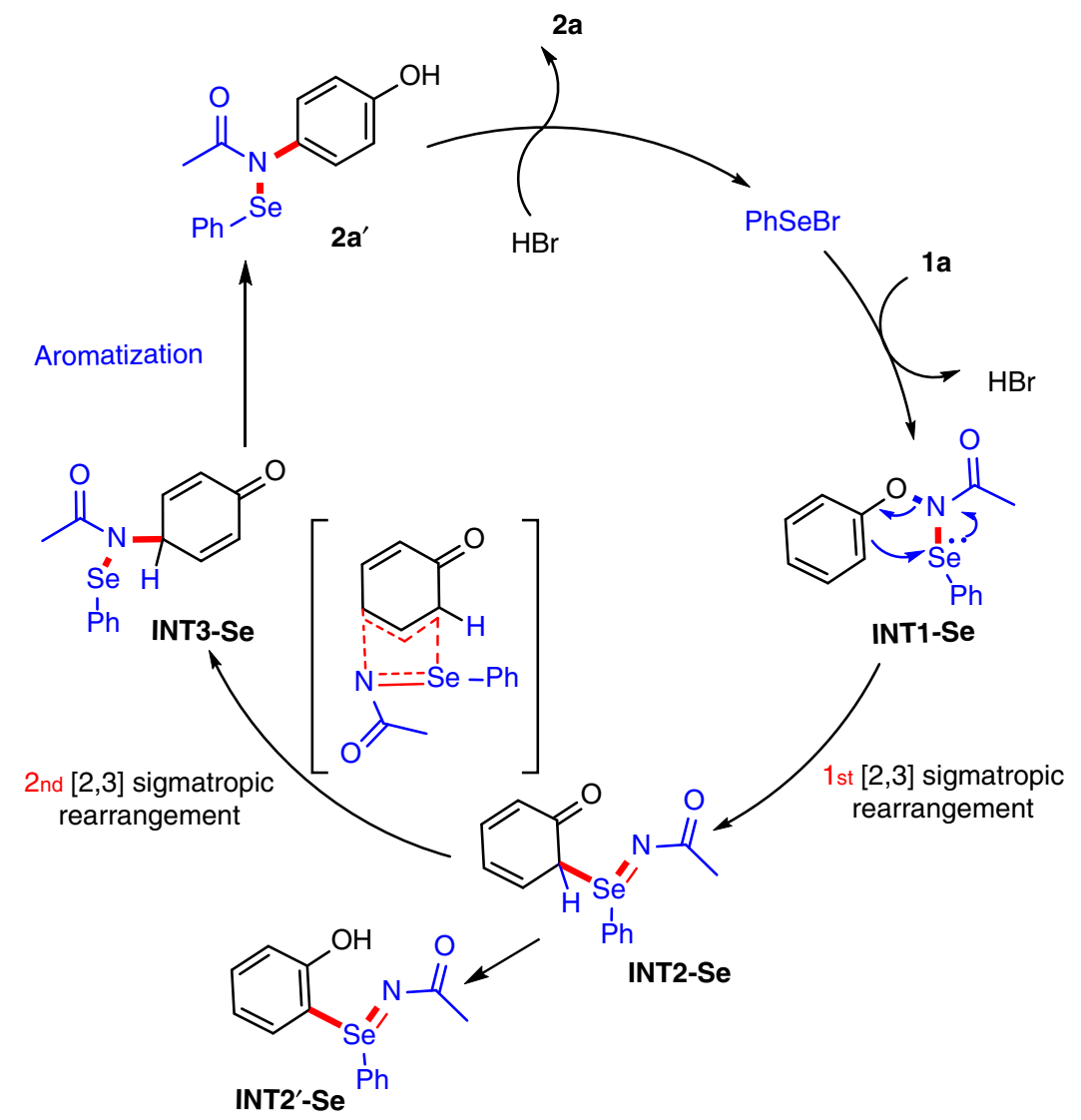

Fig. $\mathbf{2}$ Proposed catalytic cycle of the organoselenium-catalysed para-amination of phenols. A plausible mechanism illustrating how $\mathbf{2 a}$ is formed via two consecutive [2,3]-sigmatropic rearrangements

dispersion correction ${ }^{52,53}$, which already proved to be a good choice for chalcogen-containing systems ${ }^{54,55}$. For S-mediated reaction, the reaction between $N$-phenoxyacetamide 1 a and $N$ phenylthiophthalimide $\mathbf{4 g}$ was used as model reaction. The Gibbs energy profile is shown in Fig. 3a. First, the reaction of $N$ phenylthiophthalimide $\mathbf{4 g}$ and $\mathbf{1 a}$ generates the $\mathrm{S}-\mathrm{N}$ intermediate INT1-S. Then, the [2,3]-sigmatropic rearrangement of INT1-S via TS1-S forms an ortho-S $=\mathrm{N}$ substituted dearomatized species INT2-S, with a barrier of $9.7 \mathrm{kcal} \mathrm{mol}^{-1}$. Subsequently, the second [2,3]-sigmatropic rearrangement of INT2-S yields the para-amination intermediate INT3-S via TS2-S (with a barrier of $5.0 \mathrm{kcal} \mathrm{mol}^{-1}$, see path 1-S). Finally, the aromatization of INT3-S generates the desired product $\mathbf{5 g}$. The whole process is exothermic by $43.9 \mathrm{kcal} \mathrm{mol}^{-1}$, which indicates that the formation of $\mathbf{5 g}$ is reasonable. However, the barrier for the regeneration of $N$-phenylthiophthalimide $\mathbf{4 g}$ (via $\mathrm{TS}_{\mathrm{SN} 2}$ ) is up to $32.3 \mathrm{kcal} \mathrm{mol}^{-1}$, suggesting the turnover of $\mathbf{4 g}$ is difficult even under basic condition. Therefore, for S-mediated reactions, a stoichiometric amount of $N$-phenylthiophthalimide is required (see Supplementary Fig. 8 for details). For the Secatalysed reaction, the Gibbs energy profile of the reaction of $\mathbf{1 a}$ and $\mathrm{PhSeBr}$ is shown in Fig. 3b. Although the reaction of $\mathrm{PhSeBr}$ and 1a generating the Se-N intermediate INT1-Se is endothermic by $12.6 \mathrm{kcal} \mathrm{mol}^{-1}$, INT1-Se may readily undergo a Se-centred [2,3]-sigmatropic rearrangement to generate an ortho- $\mathrm{Se}=\mathrm{N}$ substituted dearomatized species (INT2-Se) via TS1-Se, with a barrier of $12.7 \mathrm{kcal} \mathrm{mol}^{-1}$. Then, another $N$ centred [2,3]-sigmatropic rearrangement of INT2-Se forms para-amination intermediate INT3-Se via TS2-Se (with a barrier of $4.4 \mathrm{kcal} \mathrm{mol}^{-1}$, see path 1-Se). Rearomatization of INT3-
Se and regeneration of the active catalyst $(\mathrm{PhSeBr})$ from $\mathbf{2} \mathbf{a}^{\prime}$ affords product $\mathbf{2 a}$ readily with large Gibbs energy-driven forces (23.5 and $16.2 \mathrm{kcal} \mathrm{mol}^{-1}$, respectively). In contrast to $N$ phenylthiophthalimide, the regeneration of $\mathrm{PhSeBr}$ is strongly exothermic by $14.7 \mathrm{kcal} \mathrm{mol}^{-1}$ with a barrier of only $15.3 \mathrm{kcal}$ $\mathrm{mol}^{-1}$ (for details see Supplementary Fig. 11). Therefore, $\mathrm{PhSeBr}$ could be used as a catalyst. In addition to path 1 , the direct rearomatization of INT2 via TS2' to generate the ortho$\mathrm{S} / \mathrm{Se}=\mathrm{N}$ substituted phenol $($ INT2') is also possible (see path 2-S in Fig. 3a and path 2-Se in Fig. 3b). However, the activation barriers of path 2 in these two systems are much higher than that of path 1. The calculated trends for the two reactions are consistent with the fact that no ortho-Se $=\mathrm{N}$ substituted phenol (or only small amount of ortho- $\mathrm{S}=\mathrm{N}$ substituted phenol) was obtained for these two types of reactions. Therefore, path 1 involving two successive [2,3]-sigmatropic rearrangements is mainly responsible for the two para-selective amination reactions (for details see Supplementary Figs 2-11 and Supplementary Data 1).

Synthetic application. To further explore the mild nature of our method, an HBT-substrate $\mathbf{1 v}$ was subjected to the reaction condition in a mixed solvent of $95 \%$ PBS buffer and 5\% 1,4dioxane (Fig. 4a). The obtained product $2 \mathbf{v}$ exhibits significant aggregation-induced emission behaviours ${ }^{56-60}$. The fluorescence intensity of the product increased gradually at $538 \mathrm{~nm}$ (Fig. 4b) in the reaction solution, accompanied by a dramatic change in emission colour from pale blue to bright yellow (Fig. 4c). 

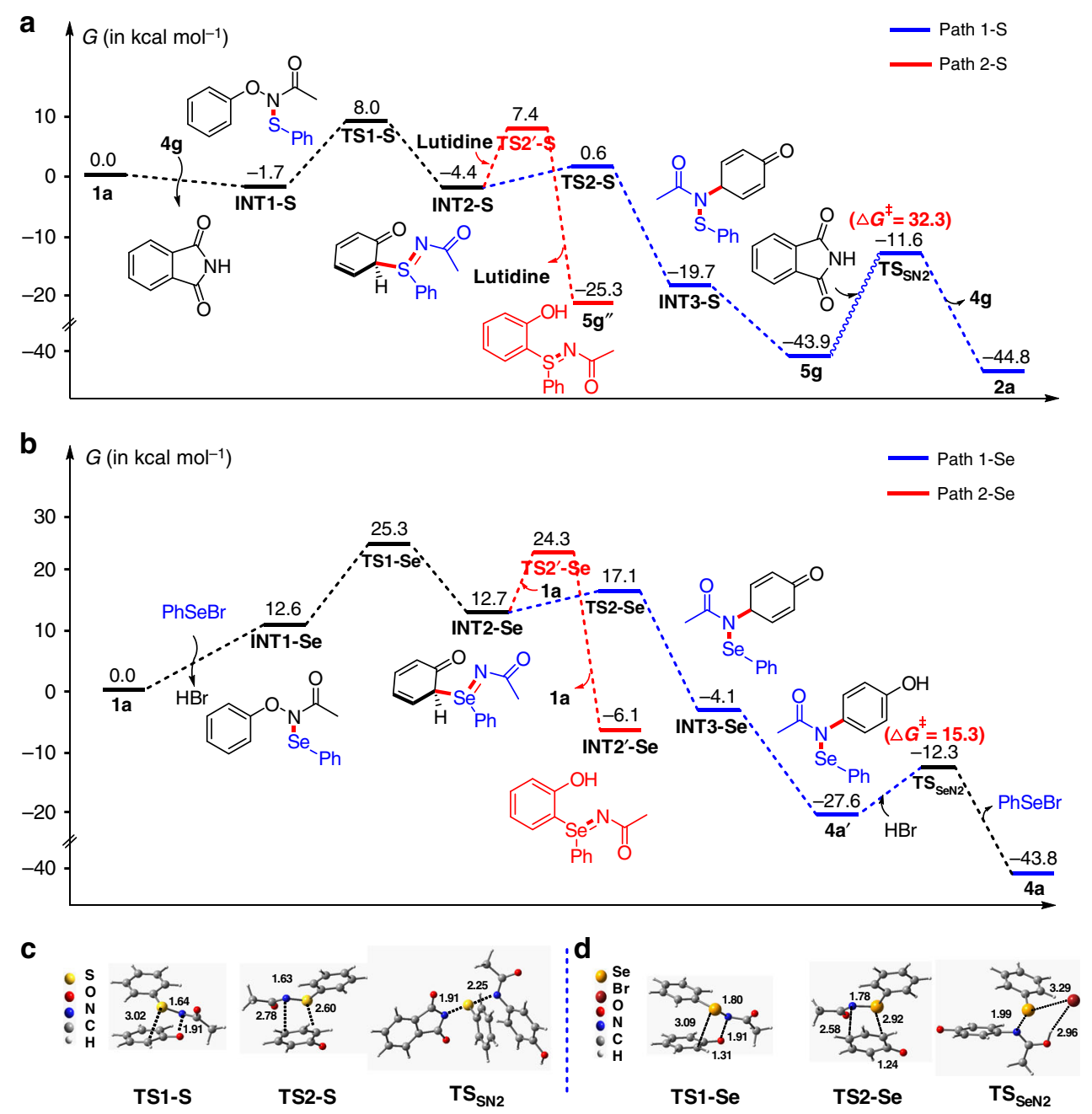

Fig. 3 Computational studies on S (and Se)-mediated para-selective nitrogen migration of $N$-phenoxyacetamide (1a). a Computed Gibbs energy profile for S-mediated reaction (in TFE). b Computed Gibbs energy profile for Se-catalysed reaction (in 1,4-dioxane). c Transition states involved in S-mediated reaction. $\mathbf{d}$ Transition states involved in Se-catalysed condition

\section{Discussion}

In summary, we discovered an organoselenium-catalysed paraamination of phenols or dienones under mild conditions. The methodology features a broad substrate scope and a high paraselectivity. More importantly, this work reveals a significant difference between the sulfenylation reagents and organoselenium reagents. While experimental and computational studies suggest that both the sulfur and selenium variants proceed through a double $[2,3]$-sigmatropic rearrangement, the sulfenylation reagents behave as coupling partners while organoselenium reagents can be employed catalytically. Because of the larger atomic radius of selenium compared to sulfur, selenium is more polarizable ("softer") than sulfur, allowing intrinsic selenium to be more nucleophilic and electrophilic ${ }^{61,62}$. Compared to sulfur, the larger hybridized orbitals of selenium results in weaker $\sigma$ overlap ${ }^{63}$. So most bond strength of $\mathrm{Se}-\mathrm{X}$ is weaker. The differences between sulfur and selenium developed here are reminiscent of their behaviours in biology. For example, the catalytic activity of the native enzyme dramatically reduces when the Sec residue in the type I ID enzyme was replaced by a cysteine (Cys) moiety ${ }^{64,65}$. We expect our present work to stimulate future studies of selenium as an alternative catalytic platform to transition metal-catalysed $\mathrm{C}-\mathrm{H}$ amination reactions.

\section{Methods}

Materials. For NMR spectra of compounds in this manuscript, see Supplementary Figs 14-73. For the crystallographic data of compound $\mathbf{2 n}$ and 5a, see Supplementary Fig. 12 and Supplementary Tables 3-15. For the representative experimental procedures and analytic data of compounds synthesized, see Supplementary Methods.

Se-catalysed standard reaction conditions. $N$-phenoxyamides (1) $(0.20 \mathrm{mmol})$, $\mathrm{PhSeBr}(10 \mathrm{~mol} \%)$, were weighed into a $10 \mathrm{~mL}$ tube, to which was added $1,4-$ dioxane $(2.0 \mathrm{~mL})$. The reaction vessel was stirred at room temperature for $8 \mathrm{~h}$. Then the mixture was concentrated under vacuum and the residue was purified by column chromatography on silica gel with a gradient eluent of petroleum ether and ethyl acetate to afford the corresponding product 2 or 3 .

S-mediated standard reaction conditions. $N$-phenoxyacetamides (1) $(0.20$ $\mathrm{mmol}), N$-substituted thiophthalimides $(4)(0.24 \mathrm{mmol})$ and 2,6-lutidine (1.0 eq.) were weighed into a $10 \mathrm{~mL}$ tube, to which was added TFE $(2.0 \mathrm{~mL})$. The reaction vessel was stirred at room temperature for $5 \mathrm{~h}$ in air. The mixture was then concentrated under vacuum and the residue was purified by column chromatography on silica gel with a gradient eluent of petroleum ether and ethyl acetate to afford the corresponding product (5).

\section{Data availability}

The X-ray crystallographic coordinates for structures reported in this study have been deposited at the Cambridge Crystallographic Data Centre (CCDC), under deposition number CCDC 1570955 and CCDC1549814. These data can be obtained free of charge from The Cambridge Crystallographic Data Centre via www.ccdc.cam.ac.uk/data_request/cif. The 
a<smiles>CC(=O)NOc1ccccc1-c1nc2ccccc2s1</smiles>

$1 \mathrm{v}$

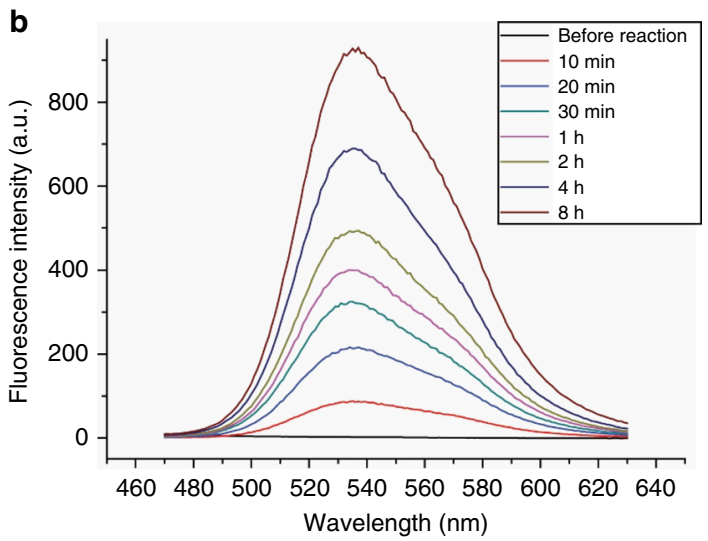

Turn on

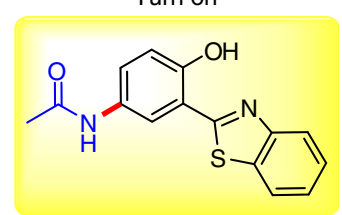

$2 v, 72 \%$

C

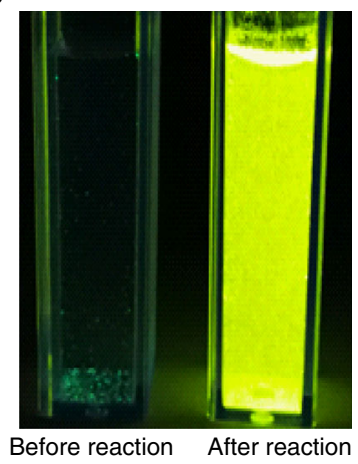

Fig. 4 Application of the Se-catalysed reaction in aqueous conditions. a Conditions: 1v (0.1 mmol), PhSeBr (10 mol\%), DMSO/PBS buffer =1:19 (4.0 mL); at ambient temperature for $8 \mathrm{~h}$; the yield was isolated yield. b Fluorescence spectra of reaction in aqueous conditions, $\lambda_{\mathrm{ex}}=380 \mathrm{~nm}$. $\mathbf{c} V$ isual fluorescence of the reaction mixture under a $365 \mathrm{~nm}$ ultraviolet lamp

authors declare that all other data supporting the findings of this study are available within the article and Supplementary Information files, and also are available from the corresponding author upon reasonable request.

Received: 11 April 2018 Accepted: 25 September 2018 Published online: 16 October 2018

\section{References}

1. Berzelius, J. J. Afh. Fys. Kemi Mineral. 6, 42 (1818).

2. Böck, A. et al. Selenocysteine: the 21 st amino acid. Mol. Microbiol. 5, 515-520 (1991).

3. Stadtman, T. C. Selenocysteine. Annu. Rev. Biochem. 65, 83-100 (1996).

4. Mousa, R., Notis Dardashti, R. \& Metanis, N. Selenium and selenocysteine in protein chemistry. Angew. Chem. Int. Ed. 56, 15818-15827 (2017).

5. Rotruck, J. T. et al. Selenium: biochemical role as a component of glutathione peroxidase. Science 179, 588-590 (1973).

6. Takahashi, K., Avissar, N., Whitin, J. \& Cohen, H. Purification and characterization of human plasma glutathione peroxidase: a selenoglycoprotein distinct from the known cellular enzyme. Arch. Biochem. Biophys. 256, 677-686 (1987).

7. Tamura, T. \& Stadtman, T. C. A new selenoprotein from human lung adenocarcinoma cells: purification, properties, and thioredoxin reductase activity. Proc. Natl. Acad. Sci. USA 93, 1006-1011 (1996).

8. Lee, S.-R. et al. Molecular cloning and characterization of a mitochondrial selenocysteine-containing thioredoxin reductase from rat liver. J. Biol. Chem. 274, 4722-4734 (1999)

9. Lescure, A., Gautheret, D., Carbon, P. \& Krol, A. Novel selenoproteins identified in silico and in vivo by using a conserved RNA structural motif. J. Biol. Chem. 274, 38147-38154 (1999).

10. Arthur, J. R., Nicol, F. \& Beckett, G. J. Hepatic iodothyronine 5'-deiodinase. The role of selenium. Biochem. J. 272, 537 (1990).

11. Behne, D., Kyriakopoulos, A., Meinhold, H. \& Köhrle, J. Identification of type I iodothyronine 5'-deiodinase as a selenoenzyme. Biochem. Biophys. Res. Commun. 173, 1143-1149 (1990).

12. Mugesh, G. \& Singh, H. B. Synthetic organoselenium compounds as antioxidants: glutathione peroxidase activity. Chem. Soc. Rev. 29, 347-357 (2000).

13. Bhabak, K. P. \& Mugesh, G. Functional mimics of glutathione peroxidase: bioinspired synthetic antioxidants. Acc. Chem. Res. 43, 1408-1419 (2010).
14. Wirth, T. Small organoselenium compounds: more than just glutathione peroxidase mimics. Angew. Chem. Int. Ed. 54, 10074-10076 (2015).

15. Bhowmick, D., Srivastava, S., D'Silva, P. \& Mugesh, G. Highly efficient glutathione peroxidase and peroxiredoxin mimetics protect mammalian cells against oxidative damage. Angew. Chem. Int. Ed. 54, 8449-8453 (2015).

16. Freudendahl, D. M., Shahzad, S. A. \& Wirth, T. Recent advances in organoselenium chemistry. Eur. J. Org. Chem. 11, 1649-1664 (2009)

17. Freudendahl, D. M., Santoro, S., Shahzad, S. A., Santi, C. \& Wirth, T. Green chemistry with selenium reagents: development of efficient catalytic reactions. Angew. Chem. Int. Ed. 48, 8409-8411 (2009).

18. Santi, C., Santoro, S. \& Battistelli, B. Organoselenium compounds as catalysts in nature and laboratory. Curr. Org. Chem. 14, 2442-2462 (2010).

19. Kratzschmar, F., Kassel, M., Delony, D. \& Breder, A. Selenium-catalysed C $\left(\mathrm{sp}^{3}\right)-\mathrm{H}$ acyloxylation: application in the expedient synthesis of isobenzofuranones. Chem. Eur. J. 21, 7030-7034 (2015).

20. Ortgies, S. \& Breder, A. Selenium-catalysed oxidative $\mathrm{C}\left(\mathrm{sp}^{2}\right)-\mathrm{H}$ amination of alkenes exemplified in the expedient aynthesis of (aza-)indoles. Org. Lett. 17, 2748-2751 (2015).

21. Ortgies, S., Depken, C. \& Breder, A. Oxidative allylic esterification of alkenes by cooperative selenium-catalysis using air as the sole oxidant. Org. Lett. 18, 2856-2859 (2016).

22. Singh, F. V. \& Wirth, T. Selenium-catalysed regioselective cyclization of unsaturated carboxylic acids using hypervalent iodine oxidants. Org. Lett. 13, 6504-6507 (2011)

23. Browne, D. M., Niyomura, O. \& Wirth, T. Catalytic use of selenium electrophiles in cyclizations. Org. Lett. 9, 3169-3171 (2007).

24. Shahzad, S. A., Venin, C. \& Wirth, T. Diselenide- and disulfide-mediated synthesis of isocoumarins. Eur. J. Org. Chem. 2010, 3465-3472 (2010).

25. Denmark, S. E., Kornfilt, D. J. \& Vogler, T. Catalytic asymmetric thio functionalisation of unactivated alkenes. J. Am. Chem. Soc. 133, 15308-15311 (2011).

26. Cresswell, A. J., Eey, S. T. \& Denmark, S. E. Catalytic, stereospecific syndichlorination of alkenes. Nat. Chem. 7, 146-152 (2015).

27. Chen, F., Tan, C. K. \& Yeung, Y. Y. C2-symmetric cyclic selenium-catalysed enantioselective bromoaminocyclization. J. Am. Chem. Soc. 135, 1232-1235 (2013).

28. Liao, L., Zhang, H. \& Zhao, X. Selenium- $\pi$-acid catalysed oxidative functionalisation of alkynes: facile access to ynones and multisubstituted oxazoles. ACS Catal. 8, 6745-6750 (2018).

29. Liu, X., An, R., Zhang, X., Luo, J. \& Zhao, X. Enantioselective trifluoromethylthiolating lactonization catalysed by an indane-based chiral sulfide. Angew. Chem. Int. Ed. 55, 5846-5850 (2016). 
30. Luo, J., Cao, Q., Cao, X. \& Zhao, X. Selenide-catalysed enantioselective synthesis of trifluoromethylthiolated tetrahydronaphthalenes by merging desymmetrization and trifluoromethylthiolation. Nat. Commun. 9, 527 (2018).

31. Liu, X., Liang, Y., Ji, J., Luo, J. \& Zhao, X. Chiral selenide-catalysed enantioselective allylic reaction and intermolecular di functionalisation of alkenes: efficient construction of $\mathrm{C}_{-} \mathrm{SCF}_{3}$ stereogenic molecules. J. Am. Chem. Soc. 140, 4782-4786 (2018).

32. Breder, A. Oxidative allylic amination reactions of unactivated olefins-at the frontiers of palladium and selenium catalysis. Synlett 25, 899-904 (2014).

33. Deng, Z., Wei, J., Liao, L., Huang, H. \& Zhao, X. Organoselenium-catalysed, hydroxy-controlled regio- and stereoselective amination of terminal alkenes: efficient synthesis of 3-amino allylic alcohols. Org. Lett. 17, 1834-1837 (2015).

34. Zhang, X., Guo, R. \& Zhao, X. Organoselenium-catalysed synthesis of indoles through intramolecular C-H amination. Org. Chem. Front. 2, 1334-1337 (2015).

35. Trenner, J., Depken, C., Weber, T. \& Breder, A. Direct oxidative allylic and vinylic amination of alkenes through selenium catalysis. Angew. Chem. Int. Ed. 52, 8952-8956 (2013).

36. Liao, L., Guo, R. \& Zhao, X. Organoselenium-catalysed regioselective C-H pyridination of 1,3-dienes and alkenes. Angew. Chem. Int. Ed. 56, 3201-3205 (2017).

37. Prasad, C. D. et al. Transition-metal-free synthesis of unsymmetrical diaryl chalcogenides from arenes and diaryl dichalcogenides. J. Org. Chem. 78, 1434-1443 (2013).

38. Silva, L. T. et al. Solvent- and metal-free chalcogenation of bicyclic arenes using $\mathrm{I}_{2} / \mathrm{DMSO}$ as non-metallic catalytic system. Eur. J. Org. Chem. 2017, 4740-4748 (2017).

39. Breder, A. \& Ortgies, S. Recent developments in sulphur- and seleniumcatalysed oxidative and isohypsic functionalisation reactions of alkenes. Tetrahedron Lett. 56, 2843-2852 (2015).

40. Denmark, S. E. \& Beutner, G. L. Lewis base catalysis in organic synthesis Angew. Chem. Int. Ed. 47, 1560-1638 (2008).

41. Denmark, S. E., Collins, W. R. \& Cullen, M. D. Observation of direct sulfenium and selenenium group transfer from thiiranium and seleniranium ions to alkenes. J. Am. Chem. Soc. 131, 3490-3492 (2009).

42. Denmark, S. E., Kalyani, D. \& Collins, W. R. Preparative and mechanistic studies toward the rational development of catalytic, enantioselective selenoetherification reactions. J. Am. Chem. Soc. 132, 15752-15765 (2010).

43. Denmark, S. E. \& Burk, M. T. Lewis base catalysis of bromo- and iodolactonization, and cycloetherification. Proc. Natl. Acad. Sci. USA 107, 20655-20660 (2010).

44. Reich, H. J. Functional group manipulation using organoselenium reagents. Acc. Chem. Res. 12, 22-30 (1979).

45. Xu, W.-M., He, J., Yu, M.-Q. \& Shen, G.-X. Site-selective modification of Vitamin D analogue (Deltanoid) through a resin-based version of organoselenium 2,3-sigmatropic rearrangement. Org. Lett. 12, 4431-4433 (2010).

46. Hans, J. R. Functional group manipulation using organoselenium reagents. Acc. Chem. Res. 12, 22-30 (1979).

47. Fankhauser, J. E., Peevey, R. M. \& Hopkins, P. B. Synthesis of protected allylic amines from allylic phenyl selenides: improved conditions for the chloramine T oxidation of allylic phenyl selenides. Tetrahedron Lett. 25, 15-18 (1984).

48. Shea, R. G. et al. Allylic selenides in organic synthesis: new methods for the synthesis of allylic amines. J. Org. Chem. 51, 5243-5252 (1986).

49. Kurose, N., Takahashi, T. \& Koizumi, T. Asymmetric [2,3]-sigmatropic rearrangement of chiral sllylic selenimides. J. Org. Chem. 61, 2932-2933 (1996).

50. Becke, A. D. Density-functional thermochemistry. III. The role of exact exchange. Exch. J. Chem. Phys. 98, 5648-5652 (1993).

51. Lee, C., Yang, W. \& Parr, R. G. Development of the Colle-Salvetti correlation-energy formula into a functional of the electron density. Phys. Rev. B Condens. Matter 37, 785-789 (1988).

52. Grimme, S., Antony, J., Ehrlich, S. \& Krieg, H. A consistent and accurate $a b$ initio parametrization of density functional dispersion correction (DFT-D) for the 94 elements H-Pu. J. Chem. Phys. 132, 154104-154119 (2010).

53. Grimme, S., Hansen, A., Brandenburg, J. G. \& Bannwarth, C. Dispersion-corrected mean-field electronic structure methods. Chem. Rev. 116, 5105-5154 (2016).

54. Bleiholder, C., Werz, D. B., Köppel, H. \& Gleiter, R. Theoretical investigations on chalcogen-chalcogen interactions: what makes these nonbonded interactions bonding? J. Am. Chem. Soc. 128, 2666-2674 (2006).
55. Gleiter, R., Haberhauer, G., Werz, D. B., Rominger, F. \& Bleiholder, C. From noncovalent chalcogen-chalcogen interactions to supramolecular aggregates: experiments and calculations. Chem. Rev. 118, 2010-2041 (2018).

56. Mei, J., Leung, N. L., Kwok, R. T., Lam, J. W. \& Tang, B. Z. Aggregationinduced emission: together we shine, united we soar! Chem. Rev. 115, 11718-11940 (2015).

57. Hu, R., Leung, N. L. \& Tang, B. Z. AIE macromolecules: syntheses, structures and functionalities. Chem. Soc. Rev. 43, 4494-4562 (2014).

58. Qian, Y. et al. Aggregation-induced emission enhancement of 2-( $2^{\prime}$ hydroxyphenyl)benzothiazole-based excited-state intramolecular protontransfer compounds. J. Phys. Chem. B 111, 5861-5868 (2007).

59. Qian, Y. et al. Restriction of photoinduced twisted intramolecular charge transfer. Chemphyschem 12, 397-404 (2010).

60. Cai, M. et al. A small change in molecular structure, a big difference in the AIEE mechanism. Phys. Chem. Chem. Phys. 14, 5289-5296 (2012).

61. Steinmann, D., Nauser, T. \& Koppenol, W. H. Selenium and sulphur in exchange reactions: a comparative study. J. Org. Chem. 75, 6696-6699 (2010).

62. Trofymchuk, O. S., Zheng, Z., Kurogi, T., Mindiola, D. J. \& Walsh, P. J. Selenolate anion as an organocatalyst: reactions and mechanistic studies. $A d v$. Synth. Catal. 360, 1685-1692 (2018).

63. Reich, H. J. \& Hondal, R. J. Why nature chose selenium. Acs. Chem. Biol. 11, 821-841 (2016).

64. Berry, M. J., Kieffer, J. D., Harney, J. W. \& Larsen, P. R. Selenocysteine confers the biochemical properties characteristic of the type I iodothyronine deiodinase. J. Biol. Chem. 266, 14155-14158 (1991).

65. Larsen, P. R. \& Berry, M. J. Nutritional and hormonal regulation of thyroid hormone deiodinases. Annu. Rev. Nutr. 15, 323-352 (1995).

\section{Acknowledgements}

Financial support was provided by the National Science Foundation of China (21622103, 21333004 and 21571098), the Natural Science Foundation of Jiangsu Province (BK20160022) and the Fundamental Research Funds for the Central Universities (No. 020514380117 and No. 020814380002).

\section{Author contributions}

D.Y. and F.X. carried out the experimental work. The computational work was conducted by G.W.; D.Y. and G.W. prepared most of the manuscript and supporting information. J.Z., S.L., Z.S., Y.L. and W.-Y.S. guided the research.

\section{Additional information}

Supplementary Information accompanies this paper at https://doi.org/10.1038/s41467018-06763-4.

Competing interests: The authors declare no competing interests.

Reprints and permission information is available online at http://npg.nature.com/ reprintsandpermissions/

Publisher's note: Springer Nature remains neutral with regard to jurisdictional claims in published maps and institutional affiliations.

Open Access This article is licensed under a Creative Commons Attribution 4.0 International License, which permits use, sharing, adaptation, distribution and reproduction in any medium or format, as long as you give appropriate credit to the original author(s) and the source, provide a link to the Creative Commons license, and indicate if changes were made. The images or other third party material in this article are included in the article's Creative Commons license, unless indicated otherwise in a credit line to the material. If material is not included in the article's Creative Commons license and your intended use is not permitted by statutory regulation or exceeds the permitted use, you will need to obtain permission directly from the copyright holder. To view a copy of this license, visit http://creativecommons.org/ licenses/by/4.0/.

(C) The Author(s) 2018 